\title{
AN UNPUBLISHED CARLYLE LETTER IN LEIPZIG
}

The University Library in Leipzig contains a hitherto unpublished holograph letter of 13 August 1834 from Thomas Carlyle to Johann Peter Eckermann (1792-1854), the friend and collaborator of Goethe in the latter's last decade (1823-32) and from 1836 the ducal librarian in Weimar. The letter forms part of the autograph collection assembled by the Rostock veterinarian Paul Nebauer (b. 1912) and given to the University Library in $1976 .{ }^{1}$ Catalogued under the shelfmark Slg. Nebauer/L/C-G/L101, the letter appears to have remained unknown to Carlyle scholars, and the unnamed recipient has not been previously identified. ${ }^{2}$ It merits attention as evidence of the facility of Anglo-German literary exchange in the 1830s and more particularly of Carlyle's close contacts with Goethe's circle in Weimar. These contacts had begun in June 1824, when the Scottish writer sent his just-published translation of Wilhelm Meister's Apprenticeship to the author, and continued long after Goethe's death in 1832.

The letter confirms how established and frequent cultural exchange between Britain and the German states was in a material sense, through shipments in both directions of books and periodicals, by the early 1830s. In his first sentence Carlyle mentions 'the Bookseller Black': this was the London bookseller Alexander Black, whose firm—founded by his father

\footnotetext{
${ }^{1}$ See Dietmar Debus, 'Die Autographensammlung Nebauer', Marginalien: Zeitschrift für
} Buchkunst und Bibliophilie, xlvi (1977), 37-42. Our thanks to the staff of the Sondersammlungen of the Universitätsbibliothek Leipzig for allowing us to examine and transcribe the letter, the publication of which is permitted under the library's Open Access policy for out-of-copyright archival material.

${ }^{2}$ Since November 2012 it has been recorded in the Kalliope online catalogue of manuscripts in German collections: kalliope-verbund.info/de/ead?ead.id=DE-611-HS-1917264. 
James in 1789 and known from 1822 to 1835 as Black, Young \& Young — was one of the leading distributors of English books to Germany and vice versa from 1815 to $1841 .^{3}$ Black's agent in Leipzig, the centre of the German book trade in the nineteenth century, was Friedrich Ludwig Herbig, whom Carlyle at the end of the letter advises Eckermann to use as his intermediary in sending books to Britain. In 1821 Black had advertised his intention to ship orders once a month via Hamburg or Leipzig, but Carlyle's letter indicates that by 1834 the shipments were weekly, presumably because of increased numbers of orders. ${ }^{4}$

The letter is valuable additionally for its assessment of Abraham Hayward's translation of the first part of Goethe's Faust. ${ }^{5}$ Carlyle had expected Hayward, a barrister and essayist, 'to have made a bungle of that business', but after reading it he praised the translation in a letter of 1 May 1833 to John Stuart Mill and an accompanying review, which in the event he never published: 'Hayward's Faust is not nearly so bad as I thought it would be: considered as a matter of Business, he has really done it most handsomely, and his Book

\footnotetext{
${ }^{3}$ Thomas Keiderling, 'Der deutsch-englische Kommissionsbuchhandel über Leipzig von
} 1800 bis 1875', Leipziger Jahrbuch zur Buchgeschichte, vi (1996), 211-82, at 234, 252, 257. Biographical information about the Blacks appears in 'The London Book Trades 1775-1800: A Preliminary Checklist of Members', Exeter Working Papers in Book History, ed. Ian Maxted (web version, 2014), bookhistory.blogspot.co.uk/2007/01/London-1775-1800-b.html (accessed 5 May 2018).

${ }^{4}$ See Keiderling, 229, for Black's statement of 1821. Keiderling also records that Asher \& Co., another leading firm in the Anglo-German book trade, shipped orders fortnightly from 1836 and weekly in the 1840 s.

\section{${ }^{5}$ Faust: A Dramatic Poem, by Goethe. Translated into English Prose, with Remarks on} Former Translations, and Notes (London, 1833). As Carlyle notes, he sent Eckermann a copy of the second edition, published in 1834. 
(glossarially) is worth something'. ${ }^{6}$ Though Carlyle's praise is hardly effusive, the new letter repeats the point expressed in the letter to Mill and the unpublished review, namely that the very modesty of Hayward's ambition, in offering a prose translation — as well as an extensive commentary - aided the comprehension of Goethe's poem better than a verse translation with its own literary pretensions would have done.

Carlyle's correspondence with Eckermann had begun in June 1828, when the German wrote to Carlyle at Goethe's behest. ${ }^{7}$ Six letters to Eckermann, dating from December 1828 to January 1849 , have been published in The Carlyle Letters Online, and three of Eckermann's to Carlyle have been published in Charles Eliot Norton's edition of the correspondence between Carlyle and Goethe. To Eckermann, as to Goethe himself, Carlyle wrote in English, while his correspondent wrote in German. The letter in the Sammlung Nebauer was written in ink on a single piece (folded once to form four pages) of wove paper, measuring $22.8 \times 18.8 \mathrm{~cm}$ and watermarked 'C ANSELL | 1834'. Here is our transcription (the question marks in square brackets follow two uncertain readings):

5. Great Cheyne Row, Chelsea, London, $13^{\text {th }}$ August, 1834-

My dear Friend,

\footnotetext{
${ }^{6}$ Thomas Carlyle and Jane Welsh Carlyle, The Carlyle Letters Online, ed. Brent E. Kinser (Durham, NC, 2007-16), www.carlyleletters.org, DOI: 10.1215/lt-18330501-TC-JSM-01 (accessed 5 May 2018 and cited hereafter as CLO; references are to the unique Digital Object Identifiers for each letter). The text of the review is published with the letter in CLO.

${ }^{7}$ The letter is published in the Correspondence between Goethe and Carlyle, ed. Charles Eliot Norton (London, 1887), 104-7 (cited hereafter as CGC).
} 
At length few days ago your Weimar Packet reached me thro' the Bookseller Black. I am already in the middle of it; for with a kind of whimsical perversity I declined reading the Nachgelassene Schriften till I could read them in my own Weimar copy, as if then only could the enjoyment be complete. I beg of you to thank the Chancellor for me in the gratefullest terms: will you also offer him that poor little Book of mine, a thing written several years ago, but only just printed ${ }^{8}$ which it is perhaps happy for me that the Chancellor (from what you say) cannot read, but [p. 2] only receive as a speechless and therefore faultless messenger of good-will from me. It is thus that for ten German Amaranths one may return a single poor Forget-me-not plucked from a Scottish ditch,- - if one have nothing better.

For yourself also there is a copy; of which I shall wish you joy. The second Edition of Hayward's Translation of Faust I lay beside it; which perhaps has not got to your hands. If it have you may know some Englisch-gesinneten ${ }^{9}$ of merit in Weimar or elsewhere, whom you delight to honour, to whom it may not be unwelcome. I have known Hayward for several years: an adroit, methodical, alertly active little fellow, who has really done a service to Faust. His prose version is in general very much what it professes to be (the authentic dried Anatomical-Preparation of Faust), and need not mislead anyone, which is a great point as we actually stand. His Notes again have been [p. 3] most unweariedly [?] collected by the person fittest perhaps of all English men for collecting; and may well throw less or more of new ${ }^{10}$

\footnotetext{
${ }^{8}$ Sartor Resartus, first published anonymously in monthly instalments of Fraser's Magazine from November 1833 to August 1834. Once the final issue was published Carlyle arranged for a private edition of fifty-eight copies to be sewn together from the magazine instalments (see the letter to Alexander Carlyle, 24 August 1834: CLO, 10.1215/1t-18340828-TC-AC-01). ${ }^{9}$ A slip for Englisch-gesinnten, Carlyle's coinage, meaning 'those well-disposed to the English'.

${ }^{10}$ This word is inserted above the line.
} 
light on the matter to almost any individual reader. Hayward finally has had the merit of proving by experiment that Goethe had at length fixed himself in the English mind; if not as an object of clear Appreciation, yet as an object of restless Curiosity never to be satisfied till it had become Appreciation. I hear that there is a fifth version of Faust about to appear printed! "It never rains but it pours", according to the Proverb. For farther proof, take this stray [?] No. of one of our Penny Journals, writter ${ }^{11}$ here by a quite un-German man for the people's reading. I would have added the preceding $\mathrm{N}^{\mathrm{o}}$., but fear, it is destroyed.

Your Post Letter, alas, still loiters. Mark my direct Address now, and do but consider the excellence both of our British Packet-boats and of your German Postwesen.

Furthermore, Black informs me that he [p. 4] receives a Book-bale from Leipzig, and transmits one thither, every week; even in the worst weather, every fortnight! Does not this bring us hundreds of leagues nearer together; almost to be door-neighbours? Black's Agent (Black, Young \& Young, Foreign Booksellers, London) is one Herr Herbig; a name, he says, known to every Bookseller in Germany. Pray inquire out this same "Herr Herbig, Buchhandler, in Leipzig” (“Black'sche Speditor”, or whatever his other titles of honour may be), and let him be our medium of communication (as I now do); the oftener the better. I mean for communication of Books; of Letters the Post is still the best carrier.

Can you excuse this haste; this undecipherable worse than fracturschrift, ${ }^{12}$ owing partly to the worst of pens. Love to all Weimar Friends; good news from you all and soon. Vergiss mein' nicht! ${ }^{13}$

\section{Ever faithfully}

\footnotetext{
${ }^{11}$ A slip for written.

${ }^{12}$ Frakturschrift, the blackletter typeface in which most German-language books were printed from the mid-sixteenth to the end of the nineteenth century.

13 'Forget me not.'
} 


\section{T. Carlyle.}

That the letter was addressed to Eckermann can easily be inferred from three internal clues. The first is the reference to the 'Nachgelassene Schriften' (actually Werke), that is, the volumes of unpublished works that Eckermann was preparing for publication as a supplement to the final authorized edition of Goethe's Werke (1827-42). ${ }^{14}$ Eckermann had written Carlyle on 20 May 1832 that he was 'much occupied' with the editing of the Nachgelassene Werke, and he summarized the contents of the fifteen volumes then planned (CGC, 328-9). On 15 August of that year Carlyle reported to his brother John, 'Black had got a Parcel from Weimar for me, when I called: 10 vols. of Goethe's Nachgelassene Werke, with a short letter from Eckermann', and on 2 December he mentioned to John the letter of 20 May:

'Eckermann wrote a very kind Letter, explaining how busy he was with redacting the 15 voll. of Nachgelassenen Schriften; the titles of all which he gave me. There is a vol of [Goethe's autobiography] Dichtung $u$. Wahrheit, and the completion of Faust: these are the most remarkable.' ${ }^{15}$ Not having received an acknowledgement of this parcel of books, Eckermann wrote Carlyle on 10 November 1833 to ask if it had ever been received. Caryle in turn responded on 6 May 1834 from Craigenputtoch, noting that he had received Eckermann's letter only 'some days ago', confirming that he had received the parcel, and lamenting that an earlier letter to Eckermann had evidently been lost in the post. ${ }^{16}$

\footnotetext{
${ }^{14}$ Goethe's nachgelassene Werke, ed. Johann Peter Eckermann and Friedrich Wilhelm Riemer, 20 vols. (Stuttgart, 1832-42; = vols. XLI-LX of Goethe's Werke: Vollständige Ausgabe letzter Hand).

${ }^{15}$ CLO, 10.1215/1t-18340815-TC-JAC-01 and 10.1215/lt-18321202-TC-JAC-01.

${ }^{16}$ CLO, 10.1215/1t-18340506-TC-JPE-01.
} 
The second clue that Eckermann was the addressee of the present letter is the reference to the 'Chancellor', meaning Friedrich von Müller (1779-1849), who had been appointed chancellor of the Grand Duchy of Sachsen-Weimar-Eisenach in 1815. Eckermann's May 1832 parcel for Carlyle had included a lecture by Müller, Goethe in seiner practischen Wirksamkeit [Goethe in His Practical Effectiveness], inscribed by its author to Carlyle and recommended by Eckermann as containing information not available elsewhere. On 2 December 1832 Carlyle described the lecture to his brother John (laconically, to be sure) as 'sensible enough', and now on 13 August 1834 he reciprocates the gift by asking Eckermann to pass on a copy of Sartor Resartus to Müller.

The final clue occurs in the paragraph about Hayward's translation of Faust I. (Part II had only recently been published by Eckermann in the Nachgelassene Werke, and the first English translation, by Robert Talbott, was to appear in 1838.) Carlyle's report of a forthcoming fifth translation recurs to a point he had made on 6 May to Eckermann, that a recent proliferation of translations attested to Goethe's status in Britain: 'within the last twelvemonths we have had no fewer than three new Translations of Faust, two of them published at Edinburgh on the same day'. ${ }^{17}$ Eckermann was eager for Carlyle to increase the knowledge of Goethe's work among British readers, and on 10 November 1833 had expressed the hope that Müller's lecture might provide him with useful material for that purpose $(C G C, 334)$. But for his part Carlyle considered, as he wrote Eckermann on the following 6 May, that his 'task in that direction, so far as it was [his] task, may be considered amply done'. In this letter of 13 August, as in that of 6 May, Carlyle adverted to the new

\footnotetext{
${ }^{17}$ As the editors of $C L O$ note, the two published in Edinburgh were by David Syme and J. S. Blackie (both 1834), while the third was Hayward's. A fourth, by Warburton Davies, was also published in 1834. Thus the one anticipated by Carlyle would be the fifth.
} 
translations of Faust I to reassure Eckermann that Goethe's place in the consciousness of the British reading public was already secure.

$\dagger$ STEPHANIE DUMKE

NICHOLAS HALMI

University of Oxford 